\title{
A Large Schwannoma of the External Auditory Canal with Adjacent Bony Erosion
}

\author{
Seung Yoon Han, MD and Jin Yoon, MD \\ Department of Otolaryngology-Head and Neck surgery, Wonkwang University Hospital, Iksan, Korea
}

\begin{abstract}
- ABSTRACT -
Schwannomas originating from the external auditory canal are relatively uncommon whereas they are commonly found in head and neck region. The authors recently experienced a 18-year-old male with a large mass in his right side external auditory canal. The mass was reported as a schwannoma and after the local excision, no symptom or sign of recurrence was identified. We report the case with literatures. (J Clinical Otolaryngol 2018;29: 250-253)
\end{abstract}

KEY WORDS : Schwannoma $\cdot$ External auditory canal $\cdot$ Benign tumor.

\section{Introduction}

Schwannomas are slow-growing benign tumors, arising from schwann cells surrounding the peripheral nerves. About $25 \%$ of the schwannomas occur in the head and neck region, ${ }^{1,2)}$ and they are commonly found from the large nerve trunks such as vagus nerve. Schwannomas of external auditory canal are rarely found.

\section{Case Report}

A 18-year-old male visited our department with the symptom of aural fullness and discomfort on his right side ear. These symptoms persisted for a month and he had no other symptoms such as otalgia, otorrhea, disturbance of sensation, or vertigo. On the oto-

논문접수일 : 2018년 9월 13일

논문수정일 : 2018년 11월 6일

심사완료일 : 2018년 11월 16일

교신저자 : 윤 진, 54538 전북 익산시 무왕로 895

원광대학교병원 이비인후과

전화 : (063) 859-1441·전송 : (063) 841-6556

E-mail:sverige80@naver.com scopic examination, there was a smooth-surfaced protruding lesion originating from the posterior wall of right external auditory canal without any color change. The mass was large enough to occupy the external auditory canal and the tympanic membrane was invisible (Fig. 1). Pure tone audiogram revealed a mild conductive hearing loss (Fig. 2).

Computed tomography (CT) scan of the temporal bone showed a well-defined soft tissue lesion on supero-posterior portion of the right external auditory canal. Mild erosion of adjacent bony structure was demonstrated on the CT scan (Fig. 3). Benign tumorous condition, non-tumorous benign subcutaneous lesion such as sebaceous gland-origin mass, or other cystic lesion could be suggested from the physical and radiologic examinations.

Surgical excision via transcanal approach with a microscope was performed under local anesthesia. Mild erosive lesion of the bony canal wall under the large mass was noted. The mass was totally removed while preserving the surrounding osteo-cartilaginous structures. Some cerumen debris trapped in due to the narrow orifice of the external auditory canal were seen on the bony portion of the canal and the tympanic membrane was found to be intact. 
Pathologic diagnosis was reported to be schwannoma. Histopathological finding shows the mass is composed of two main patterns: hypercellular area with spindled schwann cells and loosely arranged cells with variable verocay bodies (eosinophilic cores and nuclear palisading) (Fig. 4). The immunohistochemistry staining demonstrated positivity to S-100. Unfortunate-

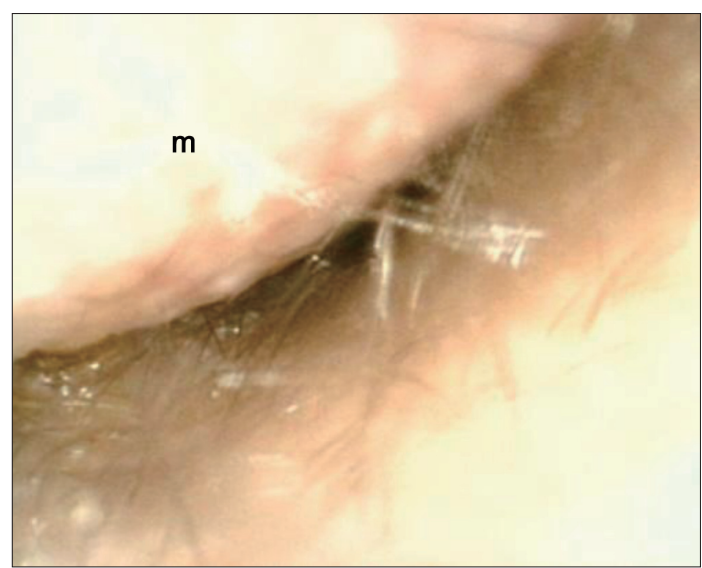

Fig. 1. Otoscopic exam shows a large, smooth-margined mass $(\mathrm{m})$ from the posterior wall of right external auditory canal. The mass is almost occupying the whole external auditory canal and the tympanic membrane is invisible. ly, the patient could not visit the clinic after the surgery, so we contacted him over the phone and checked that he had no symptom or any sign that are suspicious of the recurrence so far for a year.

\section{Discussion}

About $25 \%$ of the schwannomas occur in the head and neck region and most of them occur on the cervical area association with large nerve trunks such as vagus nerve. ${ }^{1,3,4)}$ Schwannomas arising from the otologic part are relatively less. Most of them are originated from the vestibular or facial nerve and found in the internal auditory canal or cerebellopontine angle. These tumors can cause the symptoms of hearing loss, tinnitus, vertigo and facial palsy. Few cases of schwannomas of middle ear or external ear have been reported. ${ }^{5-13)}$ In the middle ear, they occur from the Jacobson's branch of glossopharyngeal nerve, chorda tympani, facial nerve or Arnold's branch of vagus nerve. ${ }^{5,699}$

External auditory canal is innervated with the sensory branches of $\mathrm{CN} \mathrm{V}_{3}$, VII, $\mathrm{X}$ and cervical plexus $(\mathrm{C} 2, \mathrm{C} 3)$. Anterior wall is mainly innervated with the auriculotemporal nerve, origins from $\mathrm{CN} \mathrm{V}_{3}$ and pos-
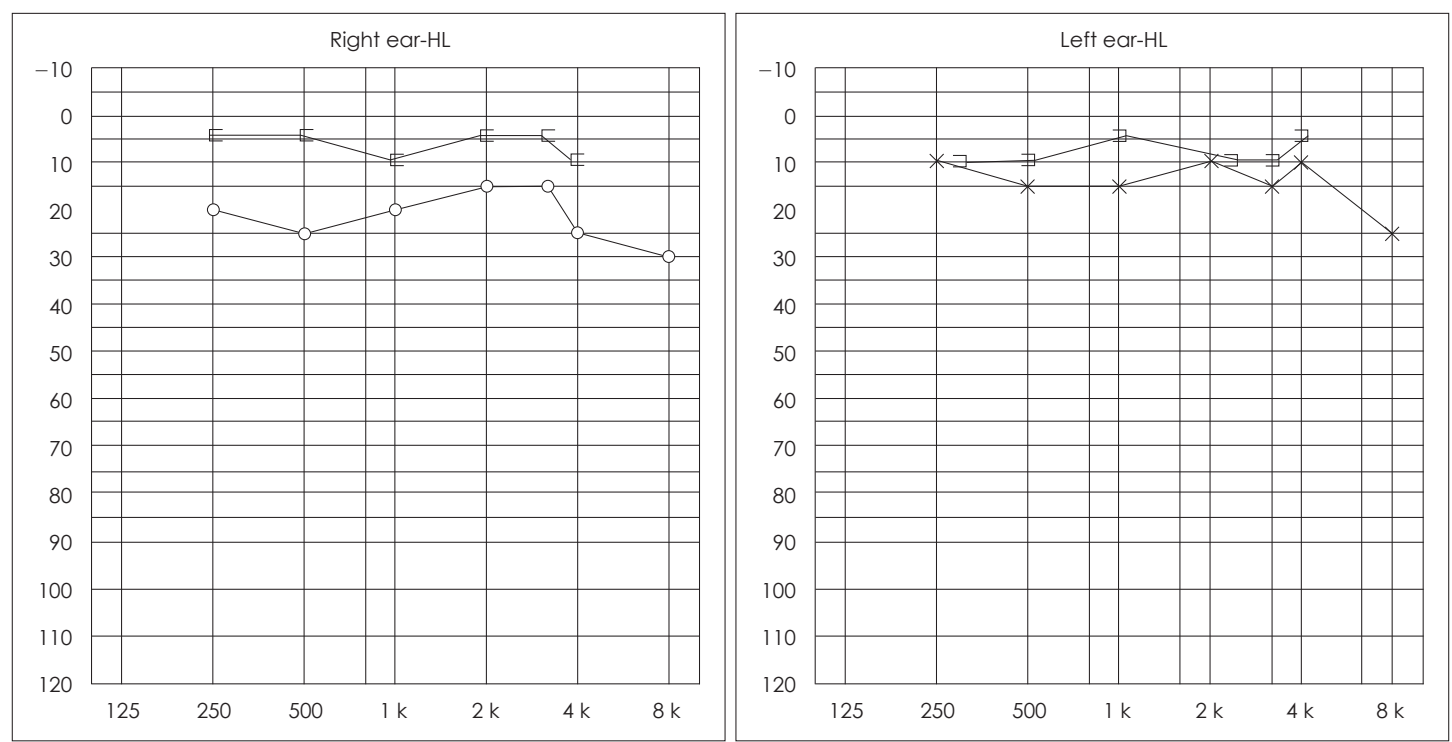

Fig. 2. Pure tone audiometry shows mild conductive type hearing loss on the right side. 

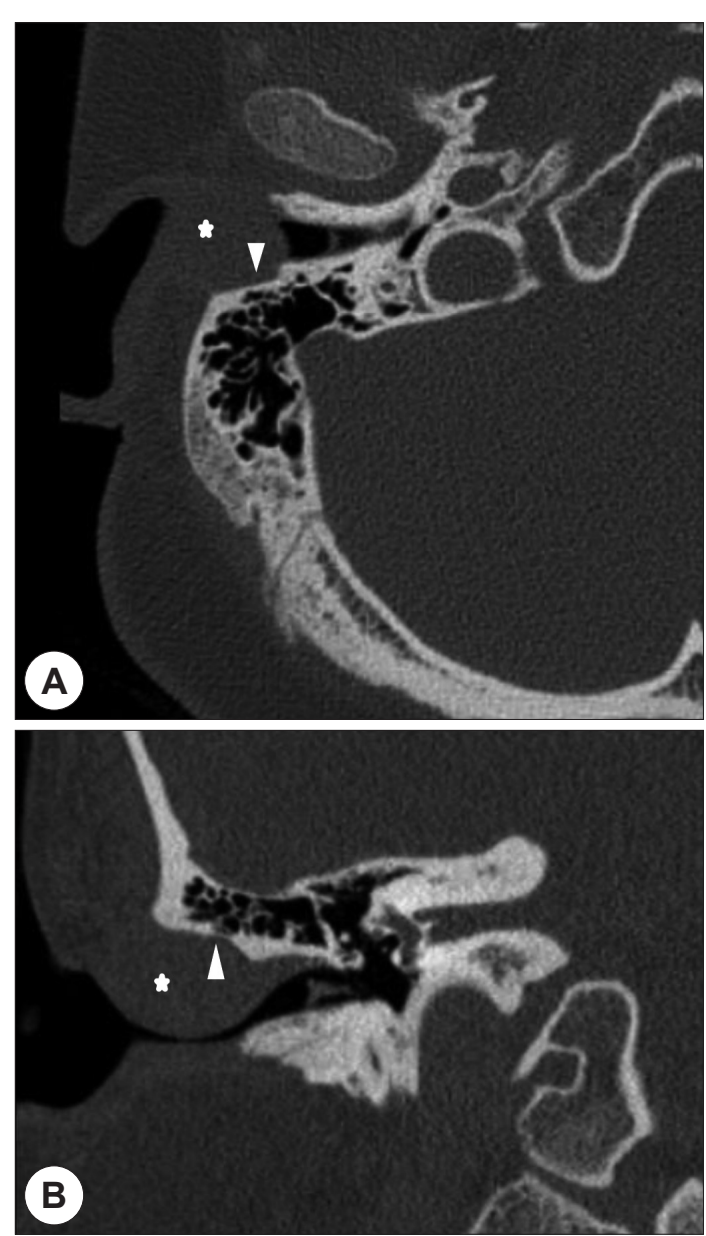

Fig. 3. Computed tomography (CT) axial (A) and coronal (B) scans of the temporal bone show a well-defined soft tissue lesion on supero-posterior portion of the right external auditory canal (asterisk). Mild erosion of adjacent bony structure was demonstrated on the CT scan (arrowhead).

terior wall with cervical plexus $(\mathrm{C} 2, \mathrm{C} 3)$. Superior portion of the canal wall is innervated with $\mathrm{CN}$ VII and inferior wall with CN X. Generally it is difficult to localize the nerve of origin on clinical examination but in our case, we suspect that the mass origins from the cervical plexus $(\mathrm{C} 2, \mathrm{C} 3)$ more likely or $\mathrm{CN} \mathrm{X}$, less likely because the mass was localized on the posterior portion of the canal wall mostly and partially on the inferior wall.

Because schwannomas are growing slowly, and

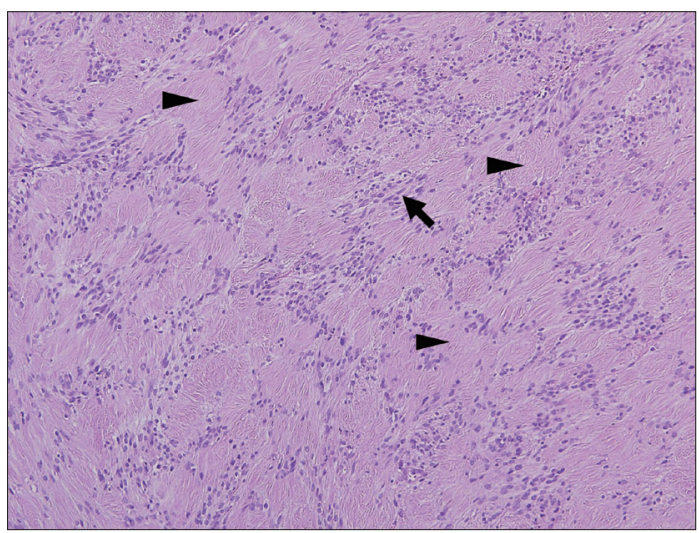

Fig. 4. Histopathological finding shows the mass is composed of spindled schwann cells with variable verocay bodies (eosinophilic cores and nuclear palisading) (H-E stain, $\times 200)$.

neurogenic symptoms such as pain or paresthesia are uncommon, ${ }^{10)}$ a mass in the external auditory canal cannot be detected early until they grow up to a huge size and cause obstructive symptoms such as mild hearing loss or aural fullness or pain.

External auditory schwannomas with erosion of the adjacent bony structure are rarely reported. Differential diagnosis of the mass in the external auditory canal consists of other soft tissue benign tumors such as nevus, fibroma, chondroma, lipoma, myxoma and neurofibromatosis. ${ }^{11)}$

Complete excision of the tumor via transcanal, endaural or postauricular approach can be considered depending on the size and the location of the mass. Before the surgical excision, CT scan or MRI can be a useful tool to find information of the size, morphological characteristics, range of the extension, condition of the adjacent anatomical structure to determine the surgical approach.

Definite diagnosis is confirmed on the basis of histopathological and immunohistochemical findings of the excised specimen. Histologically, a schwannoma is characterized by elongated spindle cells and areas consisted with thick concentrations of cells called Antoni A and areas of loose and irregularly arranged cells called Antoni B. ${ }^{11)}$ A positive S-100 proteins is the indicative of Schwann cell origin. ${ }^{11)}$ 
After complete excision, recurrence is extremely rare. Unfortunately we could not follow up the recurrence in our case because he only visited the clinic once after the surgery.

Although they are rare, schwannomas should be also considered as differential diagnosis for a benign tumorous lesion in the external auditory canal.

\section{REFERENCES}

1) Leu YS, Chang KC. Extracranial head and neck schwannomas: a review of 8 years experience. Acta Otolaryngol 2002;122(4):435-7.

2) Lee DH, Oh DH, Yoon J, Lee JH. Schwannoma originating from the superior turbinate. J Clinical Otolaryngol 2016; 27:357-61.

3) Yang $\mathrm{CH}$, Su CY, Wei YC, Hwang CF. Schwannoma of the tympanic membrane. J Laryngol Otol 2006;120:247-9.

4) Fodor RI, Pastore PN, Frable MA. Neurilemmoma of the auricle: a case report. Laryngoscope 1977;87:1760-4.

5) Bae CH, Jung DH, Oh SK, Lee JD. A case of the schwannoma originated in the middle ear cavity. Korean J Otorhinolaryngol-Head Neck Surg 2009;52(10):856-9.
6) Kim CW, Han DH, Kim CH, Cho SJ, Rho YS. Primary middle ear schwannoma. Am J Otolaryngol 2007;28(5): 342-6.

7) BH Choi, NY Do, JH Lee, SI Cho. A case of Jacobson's nerve schwannoma extending into the external auditory canal. Korean J Otorhinolaryngol-Head Neck Surg 2013; 56:373-6.

8) Ozgul T, Selim S Erbek, Seyra Erbek. Schwannoma of the external auditory canal: a case report. Head \& Face Medicine 2007;3:6

9) AydinK, Marya MM, Lo WW, Brackmann DE, Kesser B. Jacobson's nerve schwannoma presenting as middle ear mass. AJNR Am J Neuroradiol 2000;21(7):1331-3.

10) SK Yang, JC Lee, DB Shin, JK Kwon. A case of schwannoma located in the external auditory canal. Korean J Otorhinolaryngol-Head Neck Surg 2015;58(9):650-3.

11) Gross M, Maly A, Eliashar R, Attal P. Schwannoma of the external auditory canal. Auris Nasus Larynx 2005;32:77-9.

12) $\mathrm{Wu} \mathrm{CM}$, Hwang $\mathrm{CF}$, Lin $\mathrm{CH}$, Su CY. External ear canal schwannoma: an unusual case report. J Laryngo Otol 1993; 107:829-30.

13) Galli J, d'Ecclesia A, La Rocca LM, Almadori G. Giant schwannoma of external auditory canal: a case report. Otolaryngol Head Neck Surg 2001;124:473-4. 